\title{
IMPLEMENTASI FUZZY SUGENO UNTUK KINERJA PENGAJARAN DOSEN
}

\author{
Ida Afriliana ${ }^{1}$, Arfan Haqiqi Sulasmoro ${ }^{2}$, Ali Sofyan ${ }^{3}$ \\ Email : idaafriharahap@gmail.com \\ D III Teknik Komputer Politeknik Harapan Bersama, Jl. Mataram No. 09 Kota Tegal 52142, Indonesia \\ Telp/Fax (0283) 352000
}

\begin{abstract}
ABSTRAK
Trasnformasi ilmu pengetahuan dari dosen dan mahasiswa dalam proses pengajaran menjadi hal yang sangat penting dalam proses pembelajaran. Bagaimana mahasiswa dapat menyerap ilmu dan materi yang diberikan oleh dosen dipengaruhi oleh beberapa faktor diantaranya adalah kinerja dosen pengampu mata kuliah, sarana dan prasarana serta kemampuan mahasiswa itu sendiri. Pada penelitian ini akan dilakukan untuk menentukan tingkat kinerja pengajaran dosen pengampu mata kuliah dalam proses pembelajaran dengan menggunakan Fuzzy, yakni menggunakan Fuzzy Sugeno. Pengolahan data mining Fuzzy Sugeno menggunakan matlab ini diimplementasikan pada dataset hasil penilaian raport dosen pengampu di Prodi DIII Teknik Komputer pada tahun akademik 2017/2018. Dataset berjumlah 202 data dengan pengolahan data Ms.Excel untuk preposisi data kemudian akan dilanjutkan dengan pengolahan data Fuzzy Sugeno dengan 5 eksperimen yang berbeda himpunan semestanya. Dengan 3 eksperimen, yakni eksperimen pertama dengan 32 rules, himpunan keanggotaan trapmf dihasilkan tingkat 0,500; eksperimen kedua dengan 32 rules, himpunan keanggotaan trimp dihasilkan tingkat error 0,500 dan eksperimen ketiga dengan 34 rules , himpunan keanggotaan gbellmf dihasilkan tingkat error 0,505. Dengan memperhatikan tingkat error yang dihasilkan maka Fuzzy Sugeno tepat diimplementasikan untuk pengelompokkan kinerja pengajaran dosen pengampu adalah dengan 32 rules dengan trapmf atau trimp.
\end{abstract}

Kata kunci : Proses pembelajaran, Kinerja dosen, Fuzzy Sugeno.

\section{Pendahuluan}

Perkembangan teknologi data mining saat ini dapat diimplementasikan pada beberapa bidang. Termasuk diantaranya adalah penerapan data mining menggunakan Logika Fuzzy. Logika Fuzzy merupakan salah satu metode untuk menganaalisa suatu sistem yang tidak pasti ambigu. Ada beberapa logika Fuzzy yang dapat digunakan untuk melakukan pengolahan data mining diantaranya adalah fuzzy mamdani dan fuzzy sugeno.

Untuk menentukan tingkat keberhasilan dari suatu proses pembelajaran dari seorang dosen merupakan suatu hal yang penting, karena proses transformasi ilmu yang dilakukan oleh dosen kepada mahasiswa ini merupakan ujung tombak proses pembelajaran.

Prodi DIII Teknik Komputer Politeknik Harapan Bersama merupakan salah satu Perguruan Tinggi vokasi yang telah melakukan penilaian terhadap pengajaran dosen. Penilaian ini dilakukan oleh mahasiswa tentang kinerja pengajaran dosen melalui kuisioner yang dilakukan setiap akhir semester. Hasil penilaian ini diinformsikan kepada dosen pengampu dalam bentuk raport dosen, sehingga penilaian akan menjadi sumber evaluasi dosen pengampu mata kuliah pada pembelajaran berikutnya.
Tetapi bagi pengelolaan prodi, rapor dosen tidak berhenti pada tahap ini melainkan akan dilakukan proses berikutnya untuk menentukan tingkat kinerja dosen, dan dilakukan pengolahan data mining untuk menentukan keputusan atas pengajaran dosen di semester berikutnya. Penelitian ini menggunakan metode fuzzy sugeno dalam menentukan tingkat pengajaran dosen pengampu mata kuliah pada Prodi DIII Teknik Komputer.

Langkah pertama adalah menentukan variabel input dan output yang mempengaruhi pengajaran dosen yang merupakan himpunan tegas. Langkah berikutnya adalah mengubah variabel input menjadi himpunan fuzzy dengan menggunakan metode maksimum. Kemudian langkah berikutnya adalah mengubah output menjadi himpunan tegas dengan proses defuzzifikasi dengan metode centroid, sehingga akan menghasilkan hasil yang diinginkan untuk variabel outputnya.

Adapun tujuan dari penelitian ini adalah sebagai berikut:

1. Menentukan beberapa variabel yang mempengaruhi tingkat kinerja pengajaran dosen.

2. Mendapatkan output berupa tingkat pengajaran dosen dengan hasil nya adalah klasifikasi 
pengajaran dosen yang baik, cukup baik dan kurang baik.

3. Menghasilkan tingkat error yang terkecil dari beberapa eksperimen dataset hasil penilaian pengajaran dosen.

Pada penelitian yang dilakukan oleh Sundari Retni Anjani (2013) yang berjudul Fuzzy Mamdani dalam Menentukan Tingkat Keberhasilan Mengajar terdapat 3 variabel dalam menentukan keberhasilan mengajar dosen yakni dosen, nilai dan tingkat dan dihasilkan tingkat keberhasilan dosen adalah 80 .

Pada penelitian oleh Zamharil Yahya dan Fitri Handayani (2014) yang berjudul Analisis Kompetensi Terhadap Penilaian Kinerja Dosen (studi Kasus Dosen UIN Sultan Syarif Kasim Riau) menghasilkan bahwa pengaruh kompetensi pedagogik, kompetensi profesional, kompetensi kepribadian dan kompetensi sosial secara simultan (bersama-sama) sebesar 65,3\%. Yang menunjukkan ketiga variabel tersebut sangat berpengaruh signifikan.

Pada penelitian ini dilakukan pengolahan data mining untuk menentukan tingkat kinerja pengajaran dosen pengampu mata kuliah di Prodi DIII Teknik Komputer dengan menggunakan 6 variabel yakni P1 (Adanya silabus dan penyampaiannya kepada mhs), P2 (Penguasaan materi dan praktek), P3 (Metode Pengajaran ), P4 (Keterbukaan terhadap thd kritik), P5 (Kedisiplinan) dan P6 (pemenuhan administratif prodi).

Penentuan variabel berdasarkan indikator penilaian yang ada pada kuisioner yang disebarkan ekpada mahasiswa sebelum Ujian Akhir Semester dengan datasetnya adalah penilaian dosen pengampu mata kuliah pada Prodi DIII Teknik Komputer pada tahun akademik 2017/2018

Berdasarkan sumbernya metode penelitian ini hanya menggunakan data sekunder berupa data raport dosen.

Variabel P1 didapatkan dari hasil rata-rata penilaian dosen menjelaskan silabus, dosen menjelaskan kontrak kuliah dan dosen menyajikan materi perkuliahan sesuai silabus.

Variabel P2 didapatkan dari hasil rata-rata penilaian pada penguasaan dosen terhadap Materi yang diberikan dan penggunaan aplikasi pada pemberikan materi Mata Kuliah waktu di kelas dan kemudahan materi yang tersebut dapat dipahami oleh mahasiswa.

Variabel P3 didapatkan dari hasil rata-rata penilaian dosen saat menggunakan metode pengajaran kepada mahasiswa dan variasi media ajar yang dipergunakan oleh dosen pengampu mata kuliah.

Variabel P4 didapatkan dari hasil rata-rata penilaian dosen memberikan kesempatan kepada mahasiswa untuk mengajukan pertanyaan dan penghargaan dosen terhadap mahasiswa pada saat mahasiswa mengajukan pertanyaan berserta keantunan seorang dosen.

Variabel P5 didapatkan dari hasil rata-rata penilaian terhadap ketepatan dosen dalam mengajar, baik pada saat jam masuk perkuliahan atau jam keluar perkuliuahan.

Variabel P6 didapatkan dari hasil rata-rata penilaian administratif dosen kepada admin prodi, diantaranya adalah pengumpulan RPP/RPS, pengisian jurnal absensi kehadiran perkuliahan, pengumpulan soal ujian tepat waktu dan penginputan nilai ke dalam SIAKAD tepat waktu.

\section{Metode Penelitian}

Metode penelitian yang dilakukan seperti terlihat pada gambar 1.

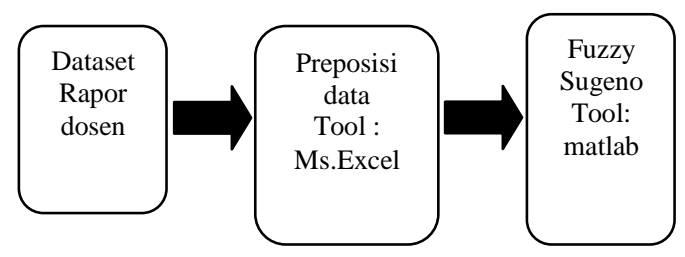

\section{Hasil dan Pembahasan}

Dataset training untuk penelitian ini sejumlah 202 data, dimana 89 data training dan 113 data testing.

Dilakukan 3 kali eksperimen dengan menggunkan himpunan keanggotaan yang berbeda yakni himpunan keanggotaan trapmf, trimp, dan gbellmf. Dengan hasil masing-masing himpunan sebagai berikut:

Tabel 1.himpunan keanggotaan trapmf dan nilai error yang dihasilan.

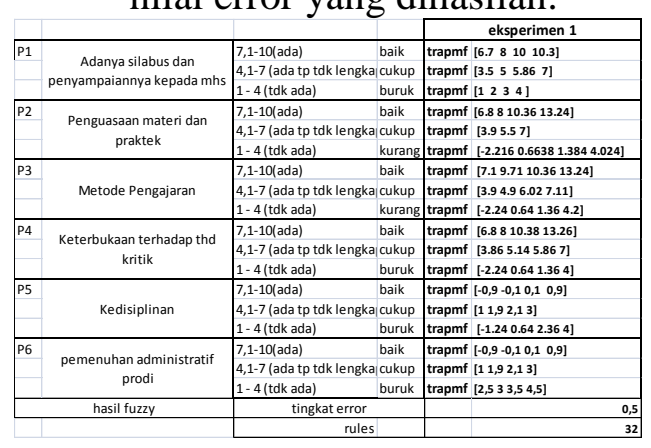


Dari tabel 1 dapat dilihat bahwa dengan membangkitan 32 rules dihasilkan tingkat error 0,500

Tabel 2.himpunan keanggotaan trim dan nilai error yang dihasilan.

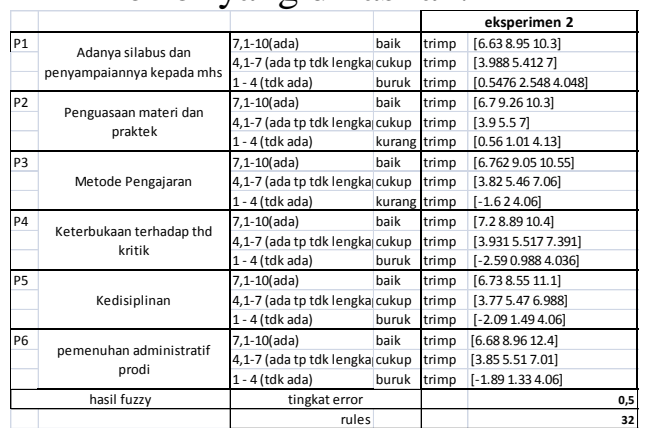

Dari tabel 2 dapat dilihat bahwa dengan membangkitan 32 rules dihasilkan tingkat error 0,500 .

Tabel 3.himpunan keanggotaan gbellmf dan nilai error yang dihasilan.

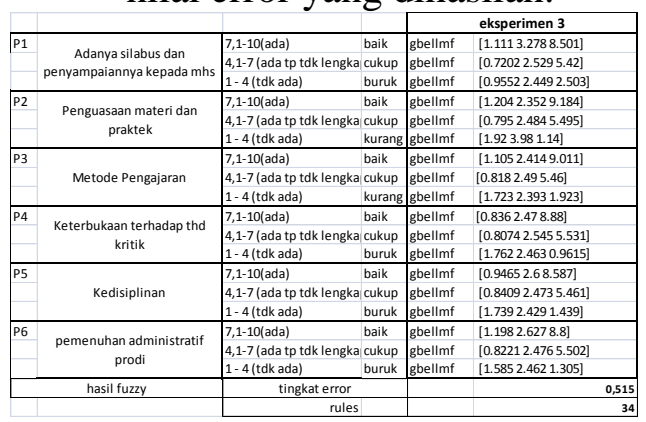

Dari tabel 3 dapat dilihat bahwa dengan membangkitan 34 rules dihasilkan tingkat error 0,505

Adapun himpunan keanggotaan pada eksperimen 2 dapat diliha pada gambar 1 sampai gambar 6.

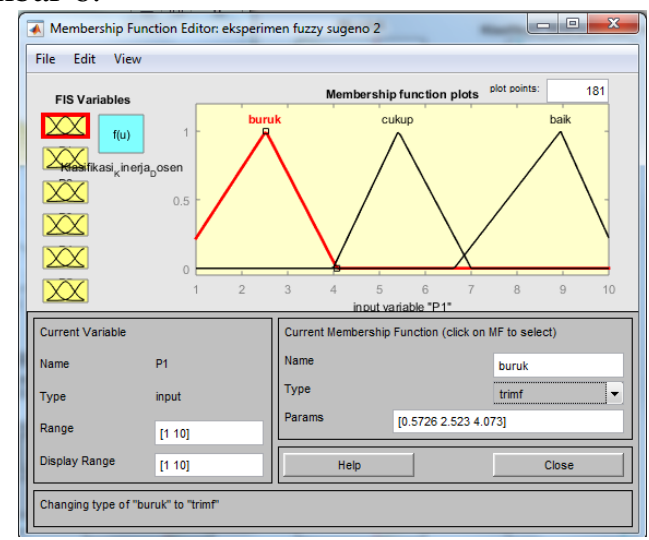

Gambar 2. Himpunan keanggotaan P1

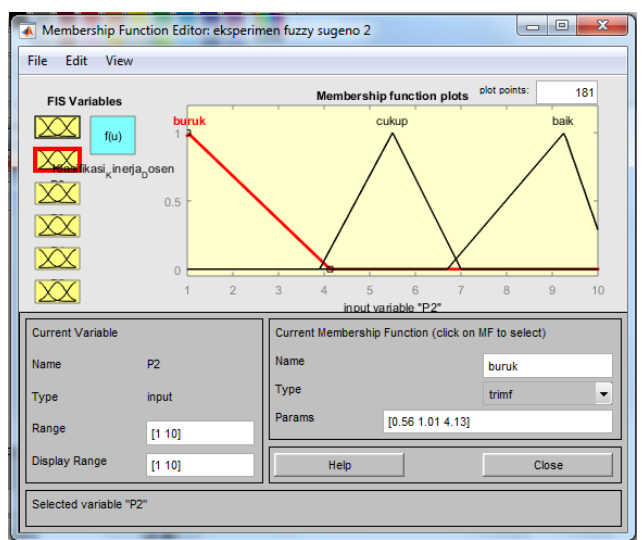

Gambar 3. Himpunan keanggotaan P2

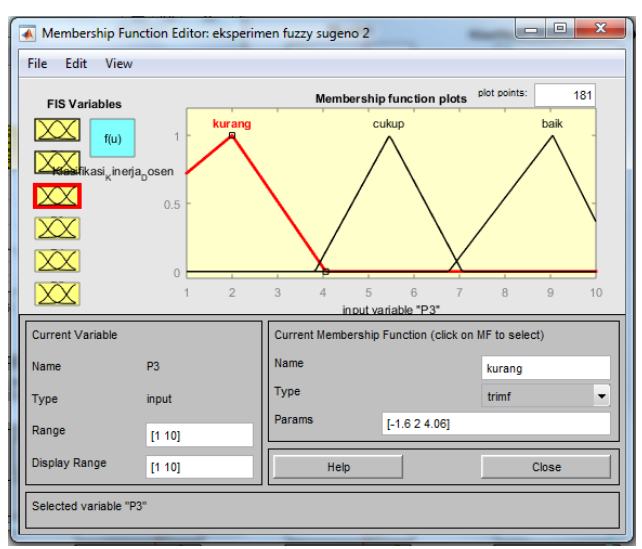

Gambar 4. Himpunan keanggotaan P3

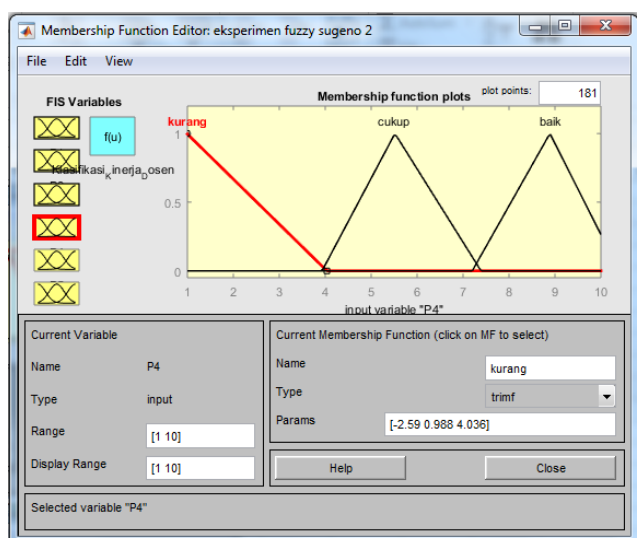

Gambar 5. Himpunan keanggotaan P4 


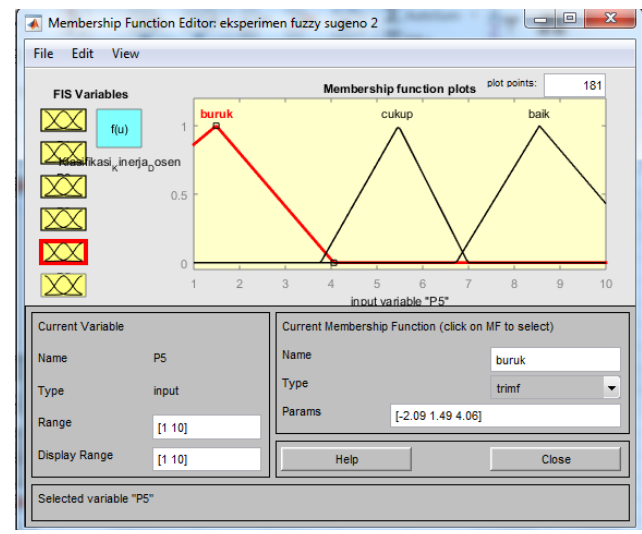

Gambar 6. Himpunan keanggotaan P5

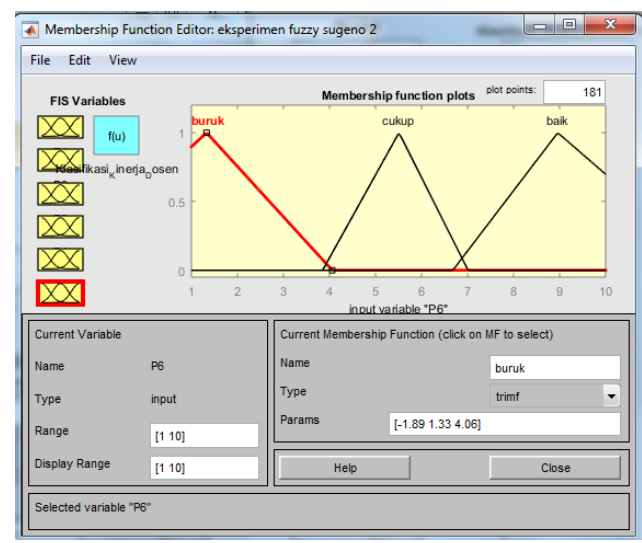

Gambar 7. Himpunan keanggotaan P6

Berdasarkan ketiga eksperimen tersebut diatas bahwa tingkat error pada eksperimen dengan himpunan keanggotaan trapmf dan trimp adalah sama yakni 0,5 dan membangkitkan jumlah rules yang sama yakni 32 , terdapat beda hasil tingkat error dihasilkan pada eksperimen ketiga yakni selisih 0,05 dan rules 34 dengan himpunan keanggotaan gbellmf.

Hasil output Tingkat kinerja dosen dari fuzzy sugeno ini ada 3 yakni kinerja dosen yang baik, kinerja dosen yang cukup dan kinerja dosen yang kurang.

Dengan plot seperti terlihat pada gambar 7 .

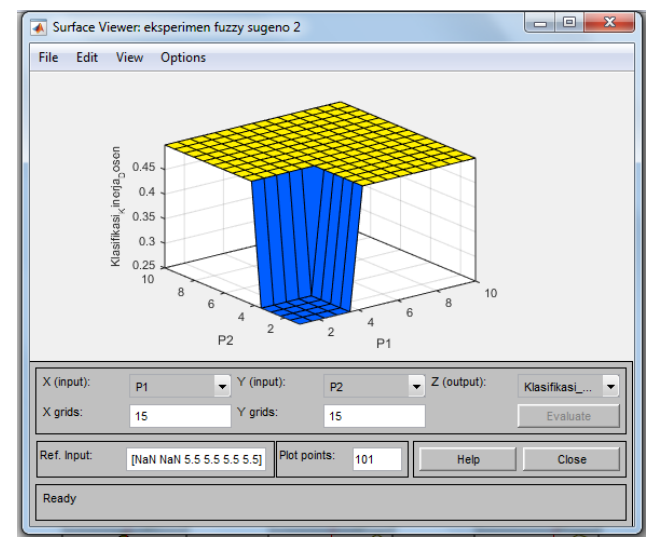

Gambar 8. Himpunan keanggotaan P6

\section{Kesimpulan}

Dengan 3 eksperimen yang berbeda diihasilkan tingkat error 0,500 dan 0,505. Maka dapat disimpulkan bahwa fuzzy sugeno mampu melakukan klasifikasi untuk tingkat kinerja pengajaran dosen. Penelitian dengan fuzzy sugeno masih dapat dikembangkan lagi dengan menggunakan metode hybrid yakni Adapative Neuro Fuzzy Inference System (ANFIS) sehingga dapat mengklasifikasi lebih baik lagi, dan diharapkan dapat mengurangi tingkat error atau memperbaiki nilai akurasi.

\section{Daftar Pustaka}

[1] Zamharil Yahya,Fitri Hidayati, 2014. "Analisis Kompetensi Terhadap Penilaian Kinerja Dosen (Studi Kasus Dosen UIN Sultan Syarif Kasim Riau)". Jurnal Penelitian Sosial Keagamaan, Volume 17, Nomor 1, Januari-Juni 2014

[2] Sundari Retno Anjani,"Fuzzy Mamdani dalam Menentukan Tingkat Keberhasilan Dosen Mengajar", Seminar Nasional Informatika, UPN, 2013

[3] Kusumadewi, S, and Purnomo, H, 2010, Aplikasi Logika Fuzzy Untuk Pendukung Keputusan, Graha Ilmu. Yogyakarta.

[4] Kusumadewi, S, 2007, Sistem Fuzzy Untuk Klasifikasi Indikator Kesehatan Daerah, Seminar TEKNOIN 2007.

[5] Zadeh, Lotfi A. 1975. Fuzzy Sets and Their Applications to Cognitive and Decision Processes. Academic Press, Inc. New York.

[6] Guanrang Chen \& Trung Tat Phan, "Introduction Fuzzy Set, Fuzzy Logic And Fuzzy Control System", ISBN 0-8493-16588,2000, halaman $28-40$ 